\title{
Comparison between different methods of urine collection for estimation of albumin-creatinine ratio in patients with type-2 diabetes mellitus
}

\author{
Subinay Datta, Mrinal Pal* \\ Department of Biochemistry, Burdwan Medical College, Burdwan, India \\ Email: ${ }^{*}$ mrinalpal77@,rediffmail.com
}

Received 8 May 2013; revised 7 June 2013; accepted 22 June 2013

Copyright (C) 2013 Subinay Datta, Mrinal Pal. This is an open access article distributed under the Creative Commons Attribution License, which permits unrestricted use, distribution, and reproduction in any medium, provided the original work is properly cited.

\begin{abstract}
In patients with diabetes mellitus, urinary albumincreatinine-ratio (ACR) predicts progressive kidney disease. In order to determine the better urine sample for detecting ACR, we estimated ACR in three modes of urine sample. Two hundred patients of uncontrolled diabetes mellitus with proteinuria irrespective of age and sex were studied for urinary ACR in all the three types of samples over a period of 2 years. The statistical analysis showed that first morning ACR ( $r$ $=0.999, \mathrm{p}>0.001$ ) of the subjects was more significantly correlated with their 24 hour urine sample ACR than spot urine $(r=0.995, p<0.001)$. We conclude that early morning specimens should be used instead of spot and 24 hour sample.
\end{abstract}

Keywords: Microalbuminuria; Albumin-Creatinine Ratio; Diabetic Nephropathy

\section{INTRODUCTION}

Diabetic nephropathy (DN) is the most frequent single cause of end-stage renal disease in many countries [1]. Hyperfiltration and microalbuminuria characterize the clinical stages of DN [2]. Increased levels of albumin in the urine have been clearly established as an important determinant for renal complication of diabetes [3-5]. Screening for increased albumin excretion has therefore been advocated to identify individual at risk for renal disease progression in a timely manner. However, there is still continuing uncertainty as to how urine should be collected and which urinary proteins should be specifically measured for prediction of renal events [6]. So, the present study therefore is to investigate which urine sample such as 24 hour, first morning void or spot urine sample is to

"Corresponding author. detect actual value of microalbuminuria for DN. But measuring only urinary albumin excretion (UAE) is not sufficient as it is influenced by intra-individual variations in urinary volume. That can be overcome by using albumincreatinine ratio $(\mathrm{ACR})$ that is dividing UAE with urinary creatinine excretion as creatinine excretion in urine has relative constancy over time [7]. So, ACR is used as a parameter to detect albuminuria in the present study.

\section{METERIAL AND METHOD}

\subsection{Selection of Subjects}

The present study was conducted in the department of Biochemistry of Burdwan Medical College, Burdwan, West Bengal. One thousand patients having age $>30$ years and suffering from uncontrolled diabetes mellitus (plasma glucose $>110 \mathrm{mg} / \mathrm{dl}, \mathrm{HbAlC}>8 \%$ of total $\mathrm{Hb}$ ) with proteinuria tested by Dipstick technique were selected. The selected patients were from Burdwan district and adjoining areas. Patients having any concomitant infection and recent history of taking drugs (e.g. NSAIDS, ACE inhibitors) were not included in the study. Then two hundred subjects were selected by a simple random method for this study.

\subsection{Collection of Samples}

After noting the age and sex, three types of urine samples (24 hour, first morning voided and random) were collected from all subjects. After collection all the tests were done immediately.

\subsection{Parameters Assay}

Albuminuria was measured by immunoturbidimetric method $[8,9]$ using semiautoanalyser (Chem $5 \mathrm{v}_{2}$ plus). Intra assay $\mathrm{CV} \%$ was 2.3 and intra assay $\mathrm{CV}$ was 3.1 for this method. Urinary creatinine concentration was assayed by 
Jaffe' method [10] using auto analyser (Transasia, XL600). Intra-assay CV\% was 1.8 and inter-assay CV\% was 2.9. Then urinary ACR was calculated. Using comercially available Hemoglobin $A_{1 C}$ kit supplied by Siemens Company did Hemoglobin $A_{1 C}$ test. It implies the principle of turbidimetric inhibition immunoassay (TINIA). This company also supplied total $\mathrm{Hb}$ kit for estimation total $\mathrm{Hb}$ by alkaline hematin method. Concentration of plasma glucose of the subjects was done by GlucoseOxidase and Peroxiase method.

\subsection{Statistical Analysis}

The data for biochemical analysis was subjected to standard statistical analysis using the Statistical Package for Social Science (SPSS) 11.5 software for windows.

\section{RESULT}

The personal profiles and clinical parameters of all the subjects under study are shown in Table 1.

Mean value of 24 hour urine ACR $(152.38 \mu \mathrm{g} / \mathrm{mg})$ are more close to first void urine $(151.11 \mu \mathrm{g} / \mathrm{mg})$ than spot urine sample $(154.85 \mu \mathrm{g} / \mathrm{mg})$. Another observation is that spot urine ACR value has higher mean, SD and has wider confidence interval than other two samples as shown in Table 2.

Table 1. Personal profiles and clinical parameters of the subjects.

\begin{tabular}{|c|c|}
\hline Age & $51.54 \pm 7.14$ \\
\hline Number of cases & $\mathrm{n}=200$ \\
\hline $\begin{array}{l}\text { Male } \\
\text { Female }\end{array}$ & $\begin{array}{l}\mathrm{n}=113 \\
\mathrm{n}=87\end{array}$ \\
\hline $\begin{array}{l}\text { Demographic data : } \\
\text { Urban background } \\
\text { Rural background }\end{array}$ & $\begin{array}{l}\mathrm{n}=129 \\
\mathrm{n}=71\end{array}$ \\
\hline Fasting plasma glucose level (mg/dl) & $168.27 \pm 24.40$ \\
\hline HbA1C level (\% of total $\mathrm{Hb})$ & $9.4965 \pm 0.997201$ \\
\hline
\end{tabular}

Value are mean $\pm \mathrm{SD} ; \mathrm{n}=$ number of cases; Reference range of fasting plasma glucose $<110 \mathrm{mg} / \mathrm{dl}$; $\mathrm{HbA} 1 \mathrm{C}>8 \%$ of total $\mathrm{Hb}$ is considered for revaluation of treatment.

Table 2. Comparison of mean value of three modes of urine samples.

\begin{tabular}{cc}
\hline Methods of urine collection & Urinary ACR $(\mu \mathrm{g} / \mathrm{mg})$ \\
\hline 24 hours urine sample & $152.38 \pm 82.26$ \\
First morning voided urine sample & $151.11 \pm 81.58$ \\
Spot urine sample & $154.85 \pm 85.75$ \\
24 hour urine vs first morning urine sample & $\mathrm{CI}=0.75148-1.77852$ \\
24 hour urine vs spot urine sample & $\mathrm{CI}=1.18-3.76991$ \\
\hline
\end{tabular}

Values are mean $\pm \mathrm{SD} ; \mathrm{CI}=$ confidence interval.
Regression analysis is performed to evaluate which method of urine collection and which sample shows best correlate with 24 hour sample. Over the whole range of 24 hour sample ACR, the first morning sample shows a higher $r$ value $(r=0.999, p<0.0001)$ and spot urine a lower $r$ value $(r=0.995, p<0.0001)$ of ACR. That signifies that first morning ACR of the subjects is more significantly correlated with their 24 hour urine sample than spot urine ACR as shown in Table 3 and Figure 1.

The area under the curve (AUC) of ROC curve of between 24 hour and early morning urine sample ACR is more than between 24 hour and spot urine ACR as shown in Table 4 and Figure 2.

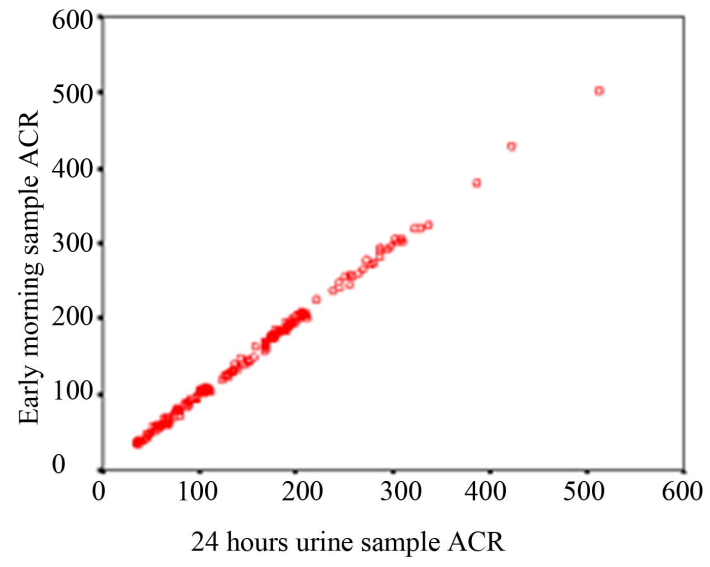

(a)

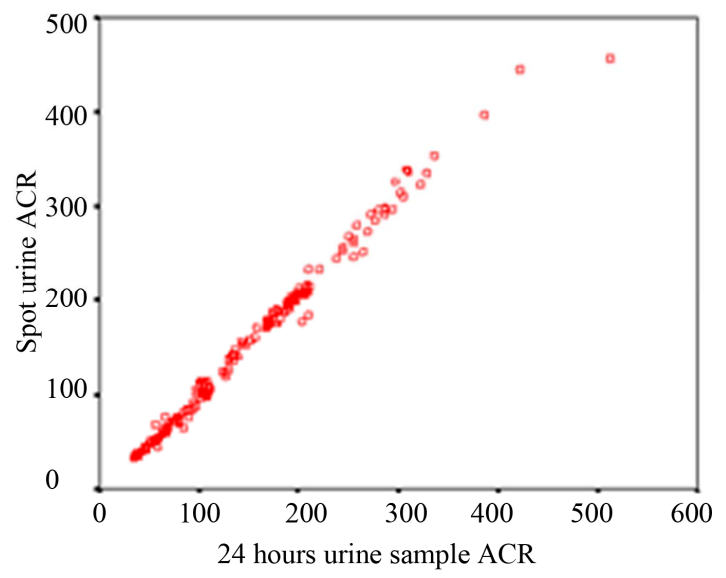

(b)

Figure 1. Scatter diagram (a) Correlation of ACR between 24 hours \& first morning urine sample (b) Correlation of ACR between 24 hours \& spot urine sample.

Table 3. Pearson's correlation of 24 hour urinary ACR with early morning and spot urine ACR.

\begin{tabular}{ccc}
\hline Category & r value & Significance \\
\hline 24 hour urine vs first morning sample & 0.999 & 0.000 \\
24 hour urine vs spot urine sample & 0.995 & 0.000 \\
\hline
\end{tabular}




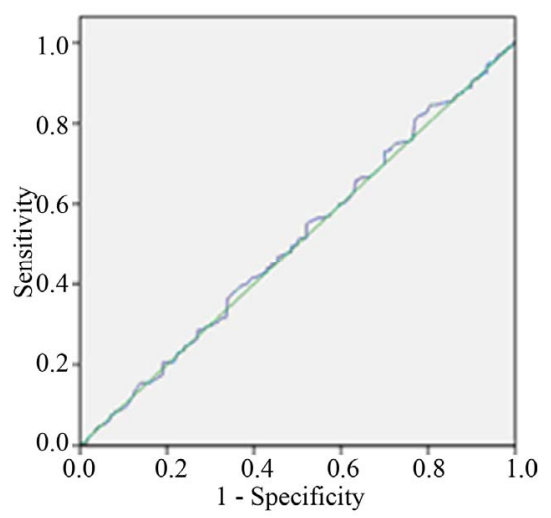

(a)

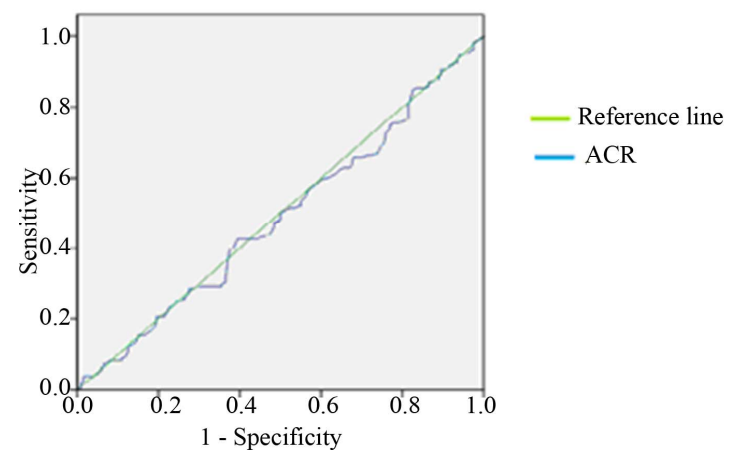

(b)

Figure 2. Receiver Operative Characteristic (ROC) curves of ACR (a) between 24 hours and early morning sample (b) between 24 hours and spot urine sample.

Table 4. Area under the ROC curve and CI between the different modes of urine sample.

\begin{tabular}{ccc}
\hline Category & $\begin{array}{c}\text { Area under } \\
\text { the ROC curve }\end{array}$ & CI \\
\hline $\begin{array}{c}\text { Between 24 hour and early } \\
\text { morning urine sample }\end{array}$ & 0.51 & $0.45-0.56$ \\
$\begin{array}{c}\text { Between 24 hour and spot } \\
\text { urine sample }\end{array}$ & 0.49 & $0.43-0.54$ \\
\hline
\end{tabular}

\section{DISCUSSION}

ACR has been proposed as both a screening and diagnostic test for kidney disease [11]. Screening for microalbuminuria is essential as it allows interventions aimed at preventing diabetic nephropathy $[12,13]$ and part of the everyday treatment of diabetic patients [14-16] for detecting kidney disease progression and also evaluation of treatment effect [17] therefore, samples providing immediate and reliable results are highly desirable. With the respect to urine collection procedure 24 hour collection were initially advocated gold standard [18-20] because of circadian rhythm of urinary protein excretion [21] and has found to be the least variable parameter for the measurement of microalbuminuria [22,23]. But 24 hour urine collection is a cumbersome procedure and subject to collec- tion errors [24-27]. More practical and easier alternatives are collection of a first morning void or a spot (random) urine sample [28-32]. Numerous recent studies have been shown that early morning urinary ACR for screening purpose is also a predictor of overt $\mathrm{DN}$ and is useful to identify patient at risk [33] as it is less influenced by the factors such as hydration status, physical activity and concentration bias $[34,27]$. In present study, when cut-off values are used that are advocated in reagent manual, the value of ACR of first void sample are closed to the value 24 hours than spot urine. So, early morning sample can replace the 24 hour sample which is too much lengthy. Various previous studies also give support towards this factor due to easy collection, low cost and high sensitivity [2,35-37].

\section{CONCLUSION}

The study concluded that early morning sample not the spot urine sample could replace the 24 hour sample for estimation of urinary ACR.

\section{ACKNOWLEDGEMENTS}

Authors are thankful to Mr. Karthik Roy, Naba Kumar Das and Chandi Charan Das of Burdwan Medical College and Hospital for technical support.

\section{REFERENCES}

[1] American Diabetes Association (2000) Diabetic nephropathy. Position statement. Diabetes Care, 23S, S69-S72.

[2] Khawali, C., Andriolo, A. and Ferreira, S.R.G. (2002) Comparison of methods for urinary albumin determination in patients with type 1 diabetes. Brazilian Journal of Medical and Biological Research, 35, 337-343. doi:10.1590/S0100-879X2002000300008

[3] de Zeeuw, D., Remuzzi, G., Parving, H.H., Keane, W.F., Zhang, Z., Shahinfar, S., Snapinn, S., Cooper, M.E., Mitch, W.E. and Brenner, B.M. (2004) Proteinuria, a target for renoprotection in patients with type 2 diabetic nephropathy, Lessons from RENAAL. Kidney International, 65, 2309-2320. doi:10.1111/j.1523-1755.2004.00653.x

[4] Ninomiya, T., Perkovic, V., de Galan, B.E., Zoungas, S., Pillai, A., Jardine, M., Patel, A., Cass, A., Neal, B., Poulter, N., Mogensen, C.E., Cooper, M., Marre, M., Williams, B., Hamet, P., Mancia, G., Woodward, M., Macmahon, S. and Chalmers, J. (2009) Albuminuria and kidney function independently predict cardiovascular and renal outcomes in diabetes. Journal of the American Society of Nephrology, 20, 1813-1821. doi:10.1681/ASN.2008121270

[5] van der Velde, M., Halbesma, N., de Charro, F.T., Bakker, S.J., de Zeeuw, D., de Jong, P.E. and Gansevoort, R.T. (2009) Screening for albuminuria identifies individuals at increased renal risk. Journal of the American Society of Nephrology, 20, 852-862. doi:10.1681/ASN.2008060655

[6] Miller, W.G., Bruns, D.E., Hortin, G.L., Sandberg, S., Aa- 
kre, K.M., McQueen, M.J., Itoh, Y., Lieske, J.C., Seccombe, D.W., Jones, G., Bunk, D.M., Curhan, G.C. and Narva, A.S. (2009) Current issues in measurement and reporting of urinary albumin excretion. Clinical Chemistry, 55, 24-38. doi:10.1373/clinchem.2008.106567

[7] Borst, J.G. and de Vries, L.A. (1950) The three types of "natural" diuresis. Lancet, 2, 1-6. doi:10.1016/S0140-6736(50)91818-6

[8] Poornima, A.M., Shenoy, R. and Hegde, A. (2010) Laboratory Assessment of the Diabetes Scenario with Respect to HbA1c and Microalbuminuria. Journal of Clinical and Diagnostic Research, 4, 2489-2494.

[9] Chang, J., Hoke, C., Ettinger, B. and Penerian, G. (1998) Evaluation and interference study of hemoglobin A1c measured by turbidimetric inhibition immunoassay. American Journal of Clinical Pathology, 109, 274-278.

[10] Husdan, H. and Rapoport, A. (1968) Estimation of Creatinine by the Jaffe raction a comparison of three methods. The American Association of Clinical Chemists, Inc., 14, 222-238.

[11] Cornell, S.J., Hollis, S., Tieszen, K.L., et al. (1994) Gender and the clinical usefulness of the albumin: Creatinine ratio. Diabetical Medicine, 11, 32-36. doi:10.1111/j.1464-5491.1994.tb00226.x

[12] Mogensen, C.E. and Christensen, C.K. (1984) Predicting diabetic nephropathy in insulin-dependent patients. New England Journal of Medicine, 311, 89-93. doi:10.1056/NEJM198407123110204

[13] Borch-Johnsen, K., Wenzel, H., Viberti, G.C. and Mogensen, C.E. (1993) Is screening and intervention for microalbuminuria worthwhile in patients with insulin dependent diabetes? British Medical Journal, 306, 17221725. doi:10.1136/bmj.306.6894.1722

[14] Mogensen, C.E., Keane, W.F., Bennett, P.H., Jerums, G, Parving, H.H., Passa, P., Steffes, M.W., Striker, G.E. and Viberti, G.C. (1995) Prevention of diabetic renal disease with special reference to microalbuminuria. Lancet, 346, 1080-1084. doi:10.1016/S0140-6736(95)91747-0

[15] Microalbuminuria Collaborative Study Group (MCSG, United Kingdom) (1993) Risk factors for development of microalbuminuria in insulin dependent diabetic patients: A cohort study. British Medical Journal, 306, 1235-1239. doi:10.1136/bmj.306.6887.1235

[16] Bennett, P.H., Haffner, S., Kasiske, B.L., Keane, W.F., Mogensen, C.E., Parving, H.H., Steffes, M.W. and Striker, G.E. (1995) Screening and management of microalbuminuria in patients with diabetes mellitus: Recommendations to the Scientific Advisory Board of the National Kidney Foundation from an ad hoc committee of the Council on Diabetes Mellitus of the National Kidney Foundation. American Journal of Kidney Disease, 25, 107-112. doi:10.1016/0272-6386(95)90636-3

[17] Warram, J.H., Gearin, G., Laffel, L., et al. (1996) Effect of duration of type I diabetes on the prevalence of stages of diabetic nephropathy defined by urinary albumin/createnine ratio. Journal of the American Society of Nephrology, 7, 930-937.

[18] Polkinghorne, K.R. (2006) Detection and measurement of urinary protein. Current Opinion in Nephrology and Hy- pertension, 15, 625-630. doi:10.1097/01.mnh.0000247502.49044.10

[19] Ali, A., Yaqub, S. and Kashif, W. (2008) Spot Urine Protein: Creatinine Ratio versus 24 hour urine protein at various levels of GFR patients referred to a tertiary care hospital of Pakistan. JPMA, 58, 476.

[20] American Diabetes Association (2001) Clinical practice recommendations 2001: Diabetic nephropathy. Diabetes Care, 24, S69-S72.

[21] Hansen, H.P., Hovind, P., Jensen, B.R. and Parving, H.H. (2002) Diurnal variations of glomerular filtration rate and albuminuria in diabetic nephropathy. Kidney International, 61, 163-168. doi:10.1046/j.1523-1755.2002.00092.x

[22] Smulders, Y.M., Slaats, E.H., Rakic, M., et al. (1998) Shortterm variability and sampling distribution of various parameters of urinary albumin excretion in patients with non-insulin-dependent diabetes mellitus. Journal of Laboratory and Clinical Medicine, 132, 39-46. doi:10.1016/S0022-2143(98)90023-3

[23] Harvey, J.N., Hood, K. and Platts, J.K. (1999) Prediction of albumin excretion rate from albumin-to-creatinine ratio. Diabetes Care, 22, 1597-1598. doi:10.2337/diacare.22.9.1597

[24] Schultz, C.J., Dalton, R.N., Turnet, C., Neil, H.A.W. and Dunger, D.B. for the Oxford Regional Prospective Study Group (2000) Freezing method affects the concentration and variability of urine proteins and the interpretation of data on microalbuminuria. Diabetic Medicine, 17, 7-14. doi:10.1046/j.1464-5491.2000.00200.x

[25] Brinkman, J.W., De Zeeuw, D., Duker, J.J., Gansevoort, R.T., Kema, I.P., Hillege, H.L., de Jong, P.E. and Bakker, S.J. (2005) Falsely low urinary albumin concentrations after prolonged frozen storage of urine samples. Clinical Chemistry, 51, 2181-2183. doi:10.1373/clinchem.2005.053777

[26] Kerr, D.N.S. (1982) Normal values in renal medicine. Medicine, 23, 1047-1053.

[27] Chadban, S., Howell, M., Twigg, S., Thomas, M., Jerums, G., Cass, A., Campbell, D., Nicholls, K., Tong, A., Mangos, G., Stack, A., MacIsaac, R.J., Girgis, S., Colagiuri, R., Colagiuri, S. and Craig, J. (2010) Assessment of kidney function in type 2 diabetes. Nephrology, 15, S146-S161. doi:10.1111/j.1440-1797.2010.01239.x

[28] Witte, E.C., Heerspink, H.J.L., Zeeuw, D., Bakker, S.J.L., Jong, P.E. and Gansevoort, R. (2009) First Morning voids are more reliable than spot urine samples to assess microalbuminuria. Journal of the American Society of Nephrology, 20, 436-443. doi:10.1681/ASN.2008030292

[29] Jermendy, G., Farkas, K., Nadas, J., Daroczy, A. and Peterfai, E. (2009) Practical aspects of measuring microalbuminuria in diabetic patients. Diabetes, Nutrition \& Metabolism, 14, 195-200.

[30] Guy, M., Borzomato, J.K., Newall, R.G., Kalra, P.A. and Price, C.P. (2009) Protein and albumin-to-creatinine ratios in random urines accurately predict $24 \mathrm{~h}$ protein and albumin loss in patients with kidney disease. Annals of Clinical Biochemistry, 46, 468-476. doi:10.1258/acb.2009.009001

[31] Witte, E.C., Lambers Heerspink, H.J., de Zeeuw, D., Bak- 
ker, S.J., de Jong, P.E. and Gansevoort, R. (2009) First morning voids are more reliable than spot urine samples to assess microalbuminuria. Journal of the American Society of Nephrology, 20, 436-443. doi:10.1681/ASN.2008030292

[32] Keane, W.F. and Eknoyan, G. (1999) Proteinuria, albuminuria, risk, assessment, detection, elimination (PARADE): A position paper of the National Kidney Foundation. American Journal of Kidney Diseases, 33, 1004-1010. doi:10.1016/S0272-6386(99)70442-7

[33] Schultz, C.J., Neil, H.A.W., Dalton, R.N. and Dunger, D.B. (2000) Risk of nephropathy can be detected before the onset of microalbuminuria during the early years after diagnosis of type 1 diabetes. Diabetes Care, 23, 18111815. doi:10.2337/diacare.23.12.1811

[34] Mogensen, C.E., Vestbo, E., Poulsen, P.L., Christiansen, C., Damsgaard, E.M., Eiskjaer, H., Froland, A., Hansen, K.W., Nielsen, S. and Pedersen, M.M. (1995) Microalbu- minuria and potential confounders: A review and some observations on variability of urinary albumin excretion. Diabetes Care, 18, 572-581.

[35] Hutchinson, A.S., O'Reilly, D.S.T.J. and MacCuish, A. (1988) Albumin excretion rate, albumin concentration and albumin/creatinine ratio compared for screening diabetics for slight albuminuria. Clinical Chemistry, 34, 20192021.

[36] Heerspink, H.J.L., Gansevoort, R.T., Brenner, B.M., Cooper, M.E., Parving, H.H., Shahinfar, S. and Zeeuw, D. (2010) Comparison of different measures of urinary protein excretion for prediction of renal events. Journal of the American Society of Nephrology, 21, 1355-1360. doi:10.1681/ASN.2010010063

[37] Tuncel, E., Erturk, E., Ersoy, C., Kiyici, S., Duran, C., Kuru, N. and Imamoglu, S. (2004) Physical activity alters urinary albumin/creatinine ratio in type 1 diabetic patient Journal of Sports Science and Medicine, 3, 49-54. 